\title{
What Williamsburg should say
}

\section{Next week's economic summit is predictable - there will be a row about the US deficit. The prize to capture is a stronger link between technology and prosperity.}

MEETINGs between heads of government such as that due to be held next week at Williamsburg, Virginia, are better remembered as opportunities for mutual misunderstanding than as occasions when the course of history is imaginatively redirected. So much is clear from what happened at the last Western economic summit at Versailles a year ago, when the issue of East-West trade in high technology was discussed, but too politely, with the result that within a few weeks the United States was at loggerheads with several Western European governments over the supply of equipment for the Soviet gas pipeline from Siberia. One obvious moral for Williamsburg is that plain speaking is in everybody's interests.

But what should the participants talk about? Rarely has the agenda for such a meeting been so closely determined by external events. After nearly a decade of economic troubles, the air is now full of the tentative cries of those who think that they have seen in the statistics evidence that the long recession may be coming to an end. The prophets of good cheer range from President Reagan to the chairmen of local chambers of commerce here and there, but their voices do not yet constitute a chorus - and, indeed, for every cheerful prophet there is another who says that economic recovery is still a long way off. Even the British Government, although in the middle of a general election, has been cautious, boasting that it has reduced the rate of inflation to 4 per cent a year but of fering no specific promises about when and how the British economy will turn the corner. The French Government is further back along the painful road the British Government has been travelling, and is being forced by crude reality to abandon the high-spending plans on which it set its heart just over two years ago. Nobody should be surprised if President Mitterrand turns out to be the most truculent of those showing up at Williamsburg. But he will be only the most outspoken of those complaining that economic life everywhere would be better if only the United States Government conducted its affairs responsibly.

For the complaint is fair enough. The huge budget deficit the US Government plans to run at least until 1985 (when the next presidential election will have come and gone) is in itself a powerful obstacle to economic recovery. The explanation is straightforward. To pay its bills, the government has to borrow money from the markets - between now and the end of June, it will have to raise more than $\$ 30,000$ million on its way. If the lender is a bank, as is predominantly the case, the result is an increase of assets and thus an increased capacity to lend money to other people. If, on the other hand, the lender is a private person, he will have lent his money to the government and not to some productive enterprise - and can get his hands on it again only by borrowing from a bank against the security of his treasury certificates by paying a higher rate of interest. So industry is robbed of funds that it might have invested in economic expansion and there is also a risk that the increased supply of credit will increase the pace of inflation. The reality of that danger was plain last week, when the simplest measure of money supply in the United States increased by $\$ 7,000$ million and promptly stimulated an increase in the short-term interest rate. The whole process is thoroughly familiar. Governments that run huge budget deficits must choose between two evils - inflation and high interest rates. In accordance with the declarations of previous economic summits going back at least to 1975, the United States has plumped for high interest rates. But because the movement of money is now thoroughly international, the consequence is that interest rates elsewhere must also be high. And so industrial recovery elsewhere is hampered by the Reagan Administration's budget policies.

That is the complaint. What response can President Reagan offer Williamsburg? To promise to do better in future, where the future means 1985 , is the most that can be hoped for at this stage. The budget deficit stems from two independent sources domestic spending, which neither side in Congress will tamper with in the year preceding a presidential election, and military spending on an unprecedented scale but on which President Reagan has staked his reputation (but may still be denied in Congress). But even a promise for the future would be worth having if it could be made in convincing terms. Once the financial markets were able to persuade themselves that interest rates would fall in the foreseeable future, they would busily set about discounting that development, banks outside the United States would be less eager to lend to the US Government, the value of the dollar would fall a little but economic activity would begin to pick up. The problem for President Reagan and his advisers, therefore, is to find a form of words that carries weight.

This central question is likely to dominate the proceedings at Williamsburg, as it should. Arguments about East-West trade in technology are unlikely to be contentious on this occasion. Arrangements intended to prevent the collapse of the international monetary system are similarly unlikely to take up much time, if only because the international banks appear to have learned to live with borrowers who repeatedly postpone the repayment of their loans. And Williamsburg is likely, like its predecessors, to utter yet another ringing call against protectionist restraints on world trade - a message that would carry more weight if only the governments participating were less zealous than they have become at trying to keep each others' commodities out. Only last month, the European Community (represented at Williamsburg) was boasting of a deal struck with Japan (also participating) whose effect will be to limit imports of Japanese videorecorders and other electronic goods to Western Europe, preferring that their own citizens should have to pay extra for these devices than that their own manufacturers should either be forced to be competitive or, better, persuaded into some field in which they can compete. And in the United States, the Commerce Committee in the House of Representatives is busily tidying up a bill designed to keep out imports of Japanese automobiles by means of a "non-tariff restraint on trade" along the lines of the bill that generated a fierce row almost exactly a year ago.

Against this background, the participants at Williamsburg will have to work hard to persuade their constituents that what they have to say is not mere window-dressing. They have one simple opportunity. These days, most governments in industrial states (and elsewhere too) have an ambition to use science and technology as a means of stimulating prosperity. The goal is plain but the means are not. On this occasion, the summit has had the wit to commission a study of opportunities for collaboration on scientific goals (see Nature 7 April, p.466) which includes a shopping list of sensible and sometimes imaginative basic research projects. The summit should give this document more than a mere casual endorsement. And it should go further, commissioning this time a study that will help at least some of the participants to make their technological dreams a little more realistic. 